\title{
Mixed Sand/Gravel Beach Response to the Beast from the East Storms
}

\author{
Authors: Dolphin, Tony, Burningham, Helene, Sifnioti, Dafni, Manning, \\ William, Wallbridge, Steven, et al.
}

Source: Journal of Coastal Research, 95(sp1) : 463-467

Published By: Coastal Education and Research Foundation

URL: https://doi.org/10.2112/SI95-090.1

BioOne Complete (complete.BioOne.org) is a full-text database of 200 subscribed and open-access titles in the biological, ecological, and environmental sciences published by nonprofit societies, associations, museums, institutions, and presses.

Your use of this PDF, the BioOne Complete website, and all posted and associated content indicates your acceptance of BioOne's Terms of Use, available at www.bioone.org/terms-of-use.

Usage of BioOne Complete content is strictly limited to personal, educational, and non - commercial use. Commercial inquiries or rights and permissions requests should be directed to the individual publisher as copyright holder.

BioOne sees sustainable scholarly publishing as an inherently collaborative enterprise connecting authors, nonprofit publishers, academic institutions, research libraries, and research funders in the common goal of maximizing access to critical research. 


\title{
Mixed Sand/Gravel Beach Response to the Beast from the East Storms
}

\author{
Centre for Environment \\ Fisheries and Aquaculture Science \\ Lowestoft, United Kindom \\ *Department of Geography \\ University College London \\ London, United Kingdom
}

Tony Dolphin ${ }^{\dagger *}$, Helene Burningham ${ }^{\ddagger}$, Dafni Sifnioti ${ }^{\dagger}$, William Manning ${ }^{\dagger}$, Steven Wallbridge ${ }^{\dagger}$, and Adrian Farcas

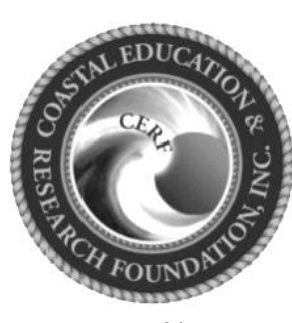

www.cerf-jcr.org

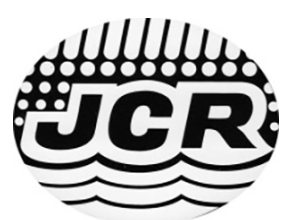

www.JCRonline.org

\begin{abstract}
Dolphin, T.; Burningham, H.; Sifnioti, D.; Manning, W.; Wallbridge, S., and Farcas, A., 2020. Mixed sand/gravel beach response to the Beast from the East storms. In: Malvárez, G. and Navas, F. (eds.), Global Coastal Issues of 2020. Journal of Coastal Research, Special Issue No. 95, pp. 463-467. Coconut Creek (Florida), ISSN 0749-0208.

Two large, very long-duration, shore-normal (easterly) storms worked on the Minsmere - Sizewell mixed sand and gravel (MSG) beach frontage (Suffolk, UK) in March 2018. These storms were unusual in their sustained high waves ( $\mathrm{Hs}>2.1 \mathrm{~m}, 97.5^{\text {th }}$ percentile) for 140 hours from the east ( $16 \%$ occurrence), compared to the regional median duration of 8.5 hours per storm. Patterns in contour advance/retreat were compared with modelled nearshore wave conditions every $100 \mathrm{~m}$ along the $3.3 \mathrm{~km}$ frontage. Although there was a positive correlation between the upper supra-tidal beach and wave period, patterns in the beach response were inconsistent and zones of common behaviour could not be explained by the wave data. Postulated explanations include spatial variation in the antecedent morphology and particle-size arrangement within the MSG sediment matrix. Despite the high magnitude of work done by these storms, the lack of barrier erosion suggests that barrier stability is likely for the present sea level under these perceived more-erosive, though less common, easterly storms.
\end{abstract}

ADDITIONAL INDEX WORDS: Storm duration, antecedent conditions, barrier stability.

\section{INTRODUCTION}

Morphodynamic models have been successfully constructed for sandy, and more recently, gravelly beaches/barriers, reflecting the development of our understanding of these systems, which is underpinned by detailed storm hydrodynamic and topographic measurement campaigns (Masselink and van Heteren, 2014). In comparison, mixed sand/gravel (MSG) beach models are lacking, and the evidence base for developing a generic understanding of these systems is also less well developed than their sandonly and gravel-only counterparts. This paper contributes to the understanding of MSG beaches by documenting the response of the Minsmere - Sizewell (Suffolk, UK) frontage to two unusually long storms, using monitoring data collected by the operators and developers of the Sizewell power stations.

\section{Study Site}

The study site is the east-facing beach between Sizewell and the Minsmere sluice outfall on the Suffolk Coast (Figure 1). The mixed sand (mode $0.35 \mathrm{~mm}$ ) and gravel (mode $22 \mathrm{~mm}$ ) beach is fronted by a sand-only double longshore bar and backed by a gravel barrier topped with dune vegetation and sands. The shoreline is gently curving except at the Minsmere outfall and adjacent to the subtidal Sizewell B (SZB) power station's outfall, where the shorelines protrude slightly seaward. The mean spring tidal range

DOI: 10.2112/SI95-090.1 received 31 March 2019; accepted in revision 13 February 2020.

*Corresponding author: tony.dolphin@cefas.co.uk

${ }^{\circ}$ Coastal Education and Research Foundation, Inc. 2020 is $2 \mathrm{~m}$. The measured bidirectional wave climate is dominated by oblique north-east (NE) (39\%), and south-south-east (SSE) (24\%) waves, giving rise to low net longshore transport. The inshore wave conditions, especially for extreme storms, are affected by wave shoaling over the Sizewell-Dunwich Bank (crest elevations $5-7 \mathrm{~m}$ below Ordnance Datum Newlyn (ODN, which is $0.13 \mathrm{~m}$ below mean sea level).

This paper specifically examines two easterly (shore-normal approach) storms in March 2018. These storms were unusual: easterly waves are less common at Sizewell (16\% occurrence), the storms occurred in close succession (11 days separation), and their durations were long - Hs exceeded $2.1 \mathrm{~m}\left(97.5^{\text {th }}\right.$ percentile, based on ten years data) for 65 and 75 hours respectively, compared to the regional median of 8.5 hours (Dhoop and Mason, 2018).

\section{METHODS}

The storm wave conditions were determined every $100 \mathrm{~m}$ along the coast at the $-5 \mathrm{~m}(\mathrm{ODN})$ contour using a calibrated spectral wave model (Tomawac) forced using wave buoy data (4 km from shore, $18 \mathrm{~m}$ depth and seaward of the Sizewell-Dunwich Bank). Pre- and post-storm beach topography were measured using polemounted RTK-GPS (10 m grid) and ground-control calibrated and validated drone photogrammetry (Structure from Motion on a $0.03 \times 0.03 \mathrm{~m}$ grid).

Changes in beach topography were analysed by extracting topographic cross-sections at each Northing corresponding to the $100 \mathrm{~m}$ alongshore-spaced wave model outputs. As each profile covers a different width on the beach, the relative distance of specific contours intersecting with the beach profile ( 0.05 to 


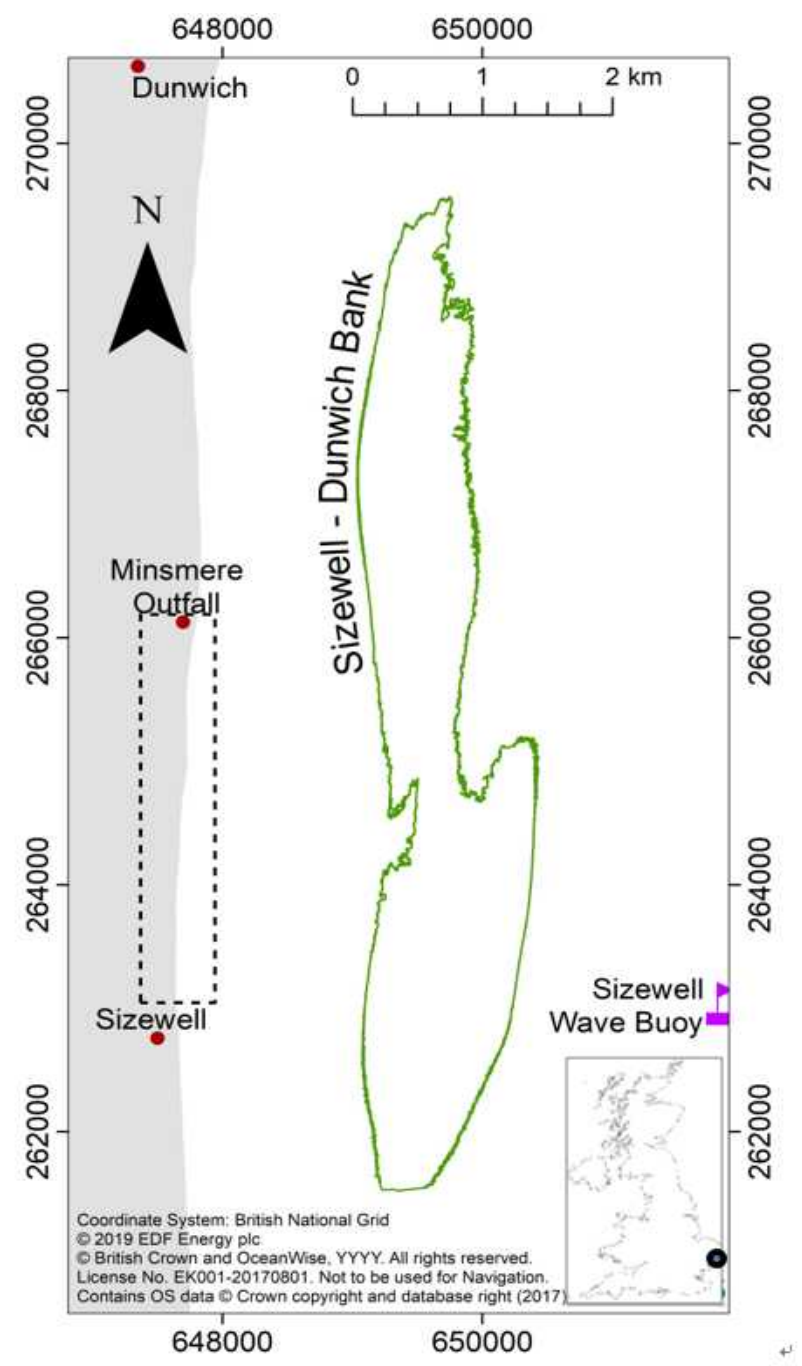

Figure 1. Map of the Minsmere to Sizewell study area (dash rectangle). The Sizewell-Dunwich Bank is indicated by the $-8 \mathrm{~m}(\mathrm{ODN})$ contour.

$2.95 \mathrm{~m}(\mathrm{ODN})$ at $10 \mathrm{~cm}$ intervals) was extracted to generate a relative-distance matrix for each contour; distances are relative to the first contour ( $0.05 \mathrm{~m} \mathrm{ODN})$. Differencing of these distances (for each contour at each Northing) then captured the nature of changing morphology - that is, a positive change relates to contour advance whilst a negative change reflects contour retreat.

Relationships between driving wave conditions at each model output and the corresponding change matrix were examined visually and, for the whole beach, by correlation analysis to explore associations between alongshore variability in morphological change (at each contour) and wave climate. Pearson and Spearman's correlation coefficients were computed for the median wave direction per storm and the $50^{\text {th }}, 75^{\text {th }}, 90^{\text {th }}$ and $99^{\text {th }}$ percentiles for significant wave height $(\mathrm{Hs})$ and peak spectral wave period (Tp). Although Spearman's correlations are more suited to non-parametric data where there is a potential for nonlinear associations, the results were very similar to Pearson's (R), which are those reported here.

\section{RESULTS}

The two easterly storms acting on the Minsmere - Sizewell coast in March 2018 are depicted in Figure 2. The first storm was formed by the combination of Storm Emma and a weakening polar vortex known as The Beast from the East (peak Hs $=4.31 \mathrm{~m}$; 65 hours). The second storm, known as the Mini Beast from the East, was also due to the weakening polar vortex (peak $\mathrm{Hs}=3.95$ $\mathrm{m} ; 75$ hours). The storms were classified as fetch-limited (easterly fetch across the southern North Sea of approximately $200 \mathrm{~km}$ ), following Hasselmann et al. (1973).

Spatial variations in the median $\mathrm{Hs}$, Tp and the relative distance change matrix are shown in Figure 3. Area $\mathbf{A}$ is associated with the reinforced concrete Minsmere Outfall $(266100 \mathrm{~N})$, which acts like a large groyne trapping sediment and anchoring the shoreline. Long-term erosion either side of the outfall has resulted in a protruding foreland, around which the median $\mathrm{Hs}$ and $\mathrm{Tp}$ were elevated (up to $0.2 \mathrm{~m}$ and $1 \mathrm{~s}$ higher than the surroundings) in both storms. The upper supra-tidal ( $>2.25 \mathrm{~m} \mathrm{ODN})$ contours, where gravel can pass over the outfall structure (c. $0.8 \mathrm{~m} \mathrm{ODN}$ ), advanced. The lower supra-tidal and intertidal contours retreated, with the exception of $265900 \mathrm{~N}$, which advanced at all elevations.

Area $\mathbf{B}$ had a comparatively low Hs and Tp (1.7 $\mathrm{m}$ and $4.5 \mathrm{~s})$ and no sustained coherent alongshore patterns in contour movement. The median Hs rose by $0.15 \mathrm{~m}$ at the Area B-C boundary, although Tp was unchanged. The general change pattern across Area $\mathbf{C}$ was coherent, with retreat of the upper supra-tidal contours and advance of the lower supra-tidal and intertidal contours (Figure 3). Despite the substantive beach reprofiling - a 'cut and fill' pattern, including the formation of a large berm (Figure 4) - beach volume was conserved. The barrier (above $3 \mathrm{~m} \mathrm{ODN)}$ behind the most changed beach profile was virtually unaltered (Figure 4 ), losing just $2 \%$ of its volume despite the high waves and long storm durations. From North to South, the retreating upper supratidal reached to progressively lower elevations.

Area D features two subtle salients (c. $300 \mathrm{~m}$ apart) and an intervening shallow bay. The interface between areas $\mathbf{C}$ and $\mathbf{D}$ had high Hs, and Tp gradually rose with distance to the south whilst Hs fell $(\mathrm{Tp}=4.5$ to $5 \mathrm{~s}$ and $\mathrm{Hs}=1.9$ to $1.7 \mathrm{~m})$. There was a marked change in beach behaviour from the cut and fill of Area $\mathbf{C}$ to varying levels of retreat at all contours for $300 \mathrm{~m}$ to the south $(263600-263800 N)$ in Area D. Hs was similar and high across the interface. The area of retreat corresponded to a salient located in the lee of the SZB outfall (140 m offshore), which eroded during the storms causing the shoreline to straighten. Retreat distances were less, and there was some advance, for contours in the prestorm embayment further south $(263400-263500 N)$. As with the northern salient, the smaller pre-storm southern salient also eroded on the lower supra-tidal and intertidal (i.e., below $2.25 \mathrm{~m}$ ODN), causing the coast to straighten.

Significant positive correlations were observed between $\mathrm{Tp}$ for both storms and the upper supra-tidal beach (Figure 5), indicating contour advance for higher Tp and vice-versa at

elevatons. Correlation with $\mathrm{Hs}$ was less convincing, with generally weaker $\mathrm{R}$ values showing a positive relation on the lower supra-tidal, i.e., contour advance with higher Hs.

Subsequent recovery of the eroded upper supra-tidal beach in Area $\mathbf{C}$ took several months, with infilling completed over the following (2018/19) winter. The salients and embayment in Area D began to redevelop four months after the storms and were prominent by six months post-storms. 


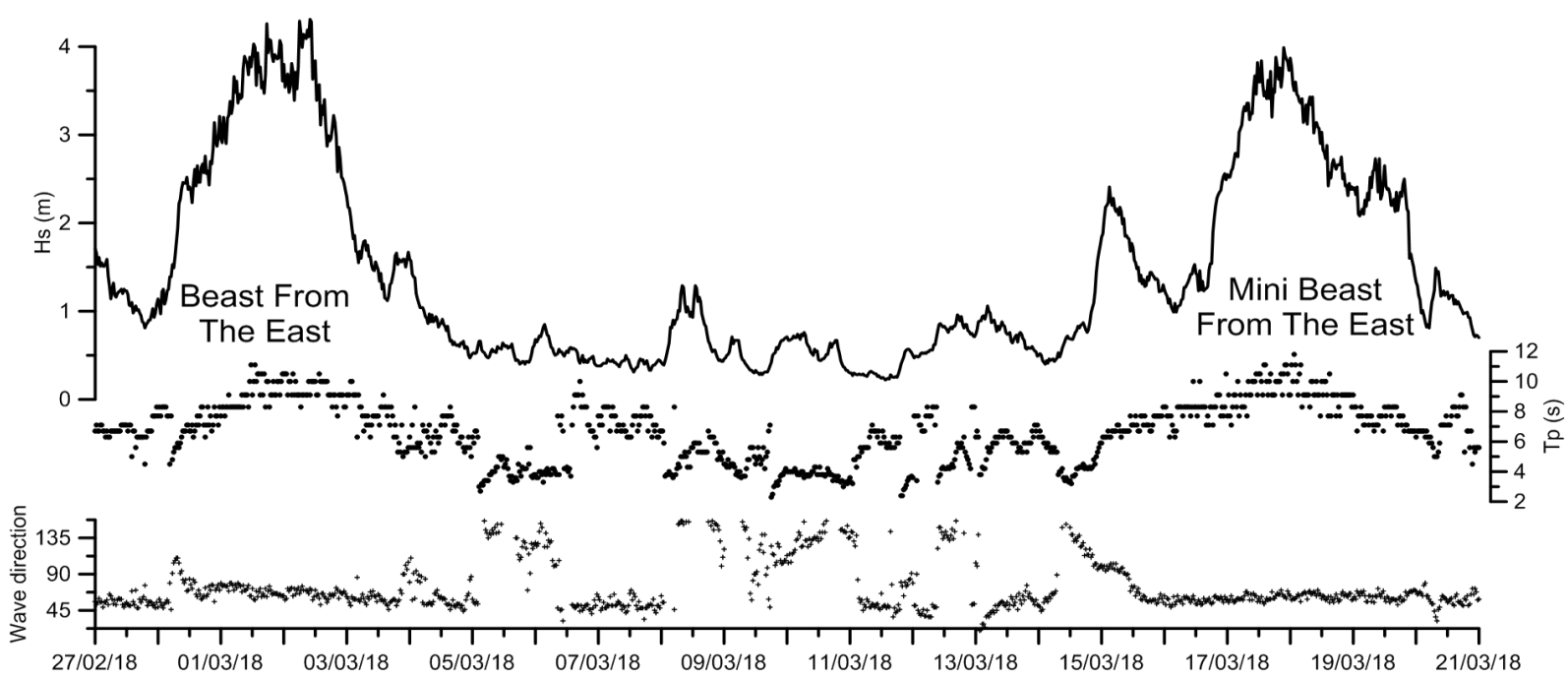

Figure 2. Offshore wave statistics associated with the Beast from the East and the Mini Beast from the East storms (Sizewell wave buoy, Figure 1).

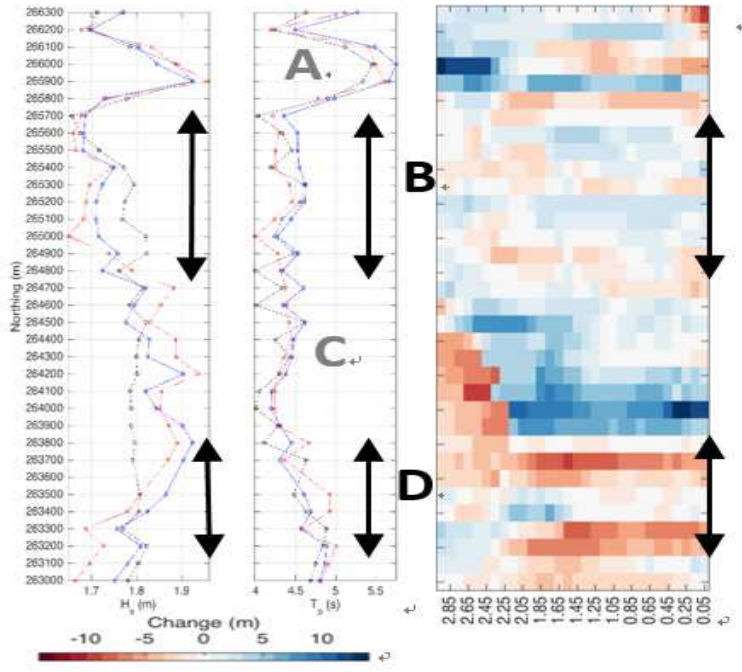

Figure 3. Alongshore patterns in $\mathrm{Hs}, \mathrm{Tp}$ (red $=$ The Beast from the East and blue $=$ the Mini Beast from the East) and the relative distance change matrix for each contour (shown on the $\mathrm{x}$-axis of the right panel). Labelled sections are described in the text.

Obliquity - the angle between wave crests and the shoreline that controls longshore transport direction and magnitude - was also investigated. Most of the shoreline had an obliquity of $8^{\circ} \pm 1.5^{\circ}$ for both events. The exceptions were at the Minsmere outfall and the Sizewell salients, where the shoreline locally deviates from that of the gradually curving bay. South of the Minsmere outfall obliquity was similar $\left(10^{\circ}\right)$ but to the north is was $-5^{\circ}$, indicating a potential tendency for diverging longshore transport, although this is not reflected in the contour analysis. Obliquity was highly variable around the Sizewell salient, ranging from $4-18^{\circ}$ with large changes from one northing to the next (e.g., there was a $12^{\circ}$ change over just $100 \mathrm{~m}$ from $263600-263700 \mathrm{~N})$, reflecting the small scale and localised effect of the salients.

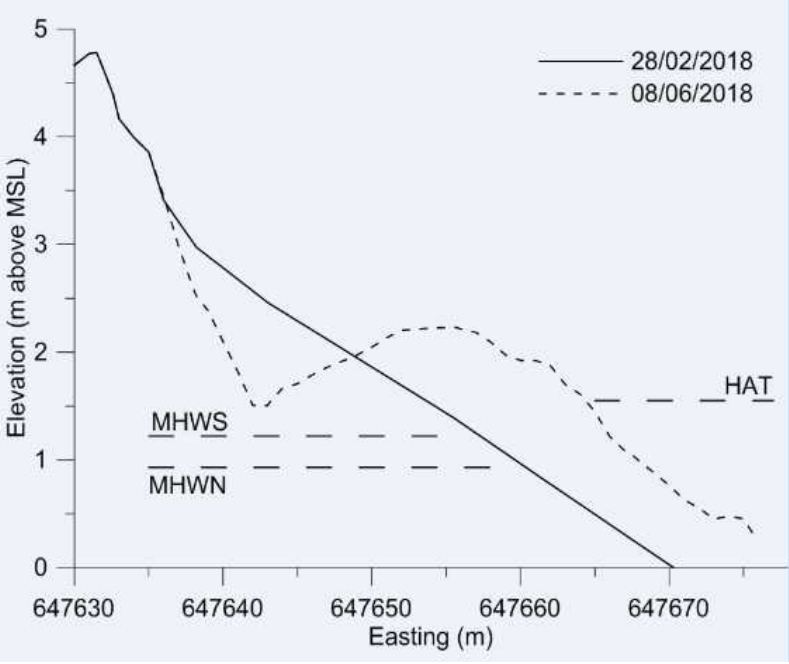

Figure 4. Pre- and post-storm profiles at 264000N. MHWS and MHWN are Mean High Water Spring and Neap elevations, respectively. HAT is the Highest Astronomical Tide.

\section{DISCUSSION}

Although peak Hs during the Beast from the East storms only equate to $1: 1$ year return interval, there were two such events within a few weeks and the annual maximum $\mathrm{Hs}$ is normally from the NE or SSE; shore-normal easterly waves of any height are uncommon, occurring just $16 \%$ of the time. Even more significant is the storm sequence and very long duration (65 and 75 hours compared to the regional median of 8.5 hours, Dhoop and Mason, 2018). The resultant sediment transport potential was very high and therefore had a high potential to erode and reshape the morphology of the Minsmere - Sizewell frontage.

The prevailing oblique storms have a larger alongshore component of wave power, which drives the event-based gross longshore transport. As the alongshore component of wave power is almost balanced (due to opposing NE and SSE storms), low 

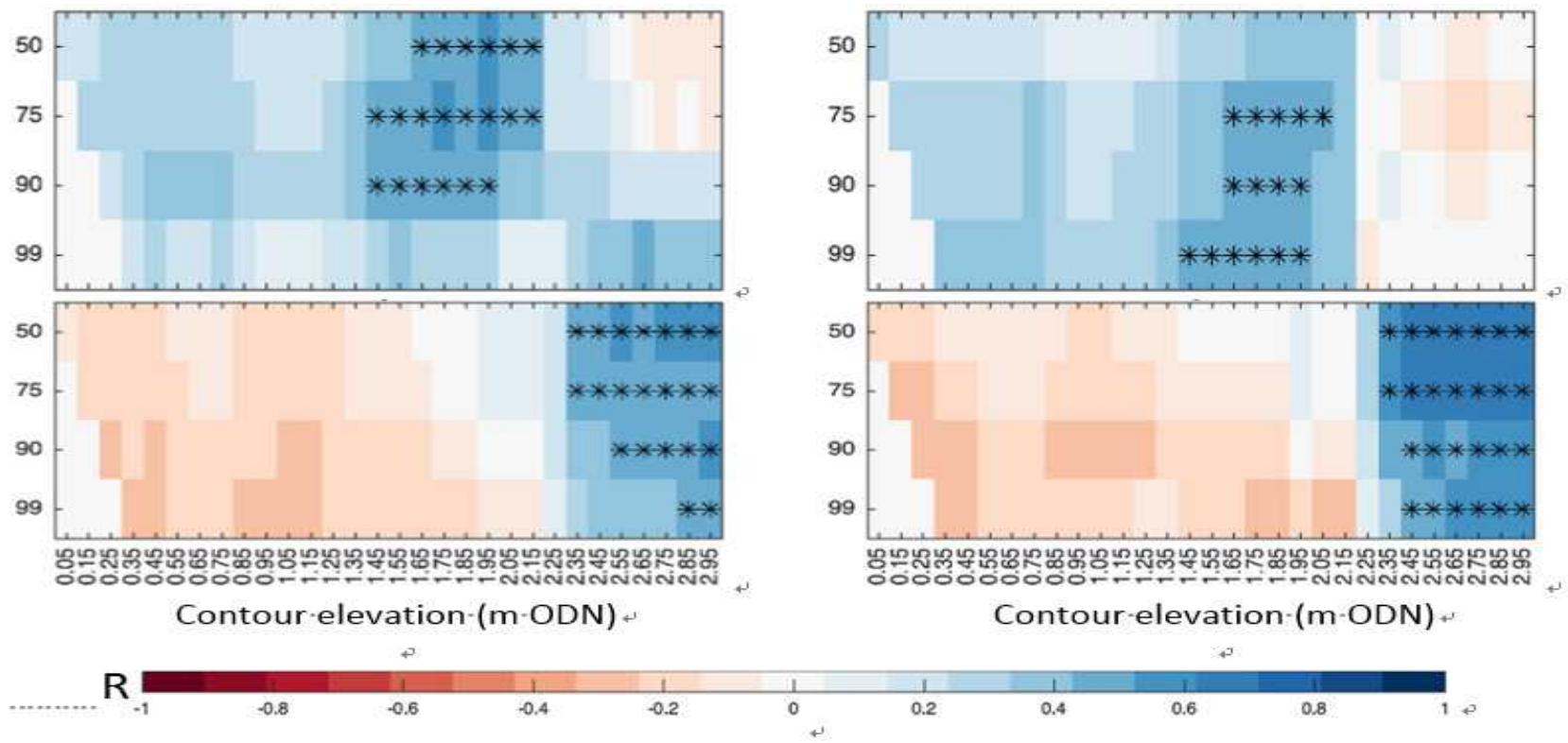

Figure 5. Correlation of the 50th, 75th, 90th and 99th percentile of Hs (top panel) and Tp (bottom panel) with contour movement. The left colum shows correlation for the Beast from the East and the right for the Mini Beast from the East. * marks correlations significant at the $99 \%$ confidence level.

net transport results (unpublished Cefas gravel tracer study, 2019) and this tends to be associated with lesser topographic changes than were observed, for example, in Area $\mathrm{C}$ under the Beast from the East storms. With less power acting on the cross-shore axis, there is less potential for beach reprofiling under oblique storms. This pattern of greater profile change for shore-normal waves, compared to oblique waves that drive longshore transport, has been observed previously (e.g., Fritz et al., 2007 and Wang et al., 2006). Furthermore, Bergillos et al. (2017) clearly demonstrated the need to consider both cross-shore and long-shore transport when modelling the storm response of gravel beaches.

However, Figure 3 shows that the Minsmere - Sizewell beach frontage has a largely non-linear and inconsistent beach response. Even along simple stretches of beach with no engineering interventions, there were no clear-cut responses or links to alongshore variation in driving waves. A positive correlation was observed between Tp and the upper supra-tidal contours, which is likely to be linked to greater run-up under longer waves. Where there were engineering elements, some patterns arose - supra-tidal accretion under higher and longer waves at the Minsmere outfall, and erosion and recovery of the sedimentary salient opposite the subtidal SZB outfall.

What are the possible explanations? Unlike their pure-sand and pure-gravel counterparts, a coherent understanding of MSG beaches is broadly lacking, and likewise for generic models (as opposed case studies) that can accurately describe their behaviour. This is perhaps not surprising. As Masselink and van Heteren (2014) explain, a likely and problematic root of this issue is the seemingly insurmountable problem of unquantifiable antecedent morphological conditions - these conditions can play a key part in beach response, and on the Minsmere - Sizewell beach frontage are not spatially uniform. That is, beach shape and morphology vary over short distances $(<100-200 \mathrm{~m})$.
Spatial variability in the antecedent arrangement of particle sizes within the beach (alongshore, cross-shore and with depth into the sediment) of the MSG beach is also likely to play an important, though unquantifiable, role in sediment mobility and availability. This could give rise to varying morphological responses under similar wave conditions (as observed in this study). Variability within an MSG beach, and from one MSG beach to the next, is a substantive challenge in attempts to understand and predict stormscale response.

A supra-tidal berm (HAT $(1.55 \mathrm{~m})$ to $2.5 \mathrm{~m}$ above ODN) present in Area $\mathbf{C}$ was flattened during the 2017/18 winter (not shown) prior to the Beast from the East. The preceeding storms responsible were in the swash regime of Sallenger's (2000) Storm Impact Scale (SIC) model for barrier erosion, causing no change to the gravel barrier. The Beast from the East storms were in the collision regime, whereby swash was able to mobilise sediments on the subaerial beach (intertidal, supra-tidal beach) but without overtopping the barrier. Despite the large degree of morphological change in the intertidal and supra-tidal beach, barrier erosion was very limited. For example, at $264000 \mathrm{~N}$ (Area C) where the most dramatic changes to the beach profile were observed (Figures 3 and 4), minimal erosion of the barrier toe resulted in a small $2 \%$ volumetric reduction.

Barrier stability shows that the severe easterly storms, despite their high gravel and morphological mobility, have limited capacity under present sea level to cause barrier erosion on the Minsmere - Sizewell frontage. The higher water levels needed to access the barrier tend to occur when storm surge and high spring tides coincide, such as the December 2013 1:200-year storm surge (peak water level of $3.26 \mathrm{~m}$ at Lowestoft $(30 \mathrm{~km}$ north of Sizewell); 1.08 m MHWS for comparison; Wadey et. al., 2015). However, although storm surge along the Suffolk coast is associated with north-easterly events that have a potential for high waves (fetch $>3000 \mathrm{~km}$ ), large surge events coinciding with high 
water tend to be associated with relatively low wave heights. For example, the 2013, 1:200 year storm had an Hs of $0.9 \mathrm{~m}$ and mean period $(\mathrm{Tz})$ of $4.8 \mathrm{~s}$. Oblique waves of a given height and period will also have a smaller runup than the same waves arriving normal (easterly) to the shore.

\section{CONCLUSIONS}

Two approximately 1:1 year (Hs) storm events approached the Minsmere - Sizewell beach frontage from the east in March 2018. The shore-normal wave angle differs from the prevailing bidirectional NE and SSE wave directions. Additionally, the storms were unusual because of their sustained high waves $(\mathrm{Hs}>2.1 \mathrm{~m}$ ) over 65 and 75 hours, compared to the regional median duration of 8.5 hours.

Although a positive correlation between Tp and the upper supratidal beach contours was observed, and the beach response showed distinct zones of behaviour - Area A showed groyne effects, B high spatial variability with no cross or alongshore patterns, $\mathbf{C}$ substantial advance of the intertidal and lower-supra-tidal, retreat of the upper supra-tidal and very little change to the barrier, and $\mathbf{D}$ salient erosion (Figure 3 ) - there are no obvious links between variation in wave parameters and the radically different responses observed. Potential causes include spatial variation in the antecedent morphology and particle-size arrangement within the mixed sand and gravel beach.

Despite the high magnitude of work done by these storms (two sequential storms both sustaining high waves over very long durations), the lack of barrier erosion suggests that barrier stability is likely for the present sea level under these perceived more-erosive, though less common, easterly storms.

\section{ACKNOWLEDGEMENTS}

This work was supported by EDF Energy Ltd (Sizewell B Power Station) and its subsidiary Nuclear New Build Generation Company (Sizewell C).

\section{LITERATURE CITED}

Bergillos, R.J.; Ortega-Sánchez, M.; Masselink, G., and Losada, M.A., 2017. Morpho-sedimentary dynamics of a micro- tidal mixed sand and gravel beach, Playa Granada, southern Spain. Marine Geology 379 (2016) 28-38. http://dx.doi. org/10.1016/j.margeo.2016.05.003

Dhoop, T. and Mason, T. 2018. Spatial Characteristics and Duration of Extreme Wave Events around the English Coastline. Journal of Marine Science and Engineering. 6(1), 14. DOI: $10.3390 /$ jmse6010014

Fritz, H.M.; Blount, C.; Sokoloski, R.; Singleton, J.; Fuggle, A.; McAdoo, B.G.; Moore, A.; Grass, C., and Tate, B., 2007. Hurricane Katrina storm surge distribution and field observations on the Mississippi Barrier Islands. Estuarine, Coastal and Shelf Science, 74, 12 - 20, https://doi. org/10.1016/j.ecss.2007.03.015.

Hasselman, K.; Barnett, T.P.; Bouws, E.; Carlson, H.; Cartwright, K.; Enke, K.; Ewing, J.A.; Gienaoo, H.; Hasselmann, D.E.; Kruseman, P.; Meerburg, A.; Muller, P.; Pibers, D.J.; Richter, K.; Sel. W., and Walden, K., 1973. Measurements of WindWave Growth and Swell Decay during the Joint North Sea Wave Project (JONSWAP). Deutsche Hydrographische Zeitschrift, Supplement A8, 1973.

Masselink, G. and van Heteren, S., 2014. Response of wavedominated and mixed-energy barriers to storms. Marine Geology 352 (2014) 321-347, http://dx.doi.org/10.1016/j. margeo.2013.11.004

Sallenger, A.H., 2000. Storm impact scale for barrier islands. Journal of Coastal Research, 16 (3), 890 - 895.

Wadey, M. P.; Brown, J. M.; Haigh, I. D.; Dolphin, T., and Wisse, P., 2015. Assessment and comparison of extreme sea levels and waves during the 2013/14 storm season in two UK coastal regions. Natural Hazards and Earth System Sciences, 15, 2209-2225, https://doi.org/10.5194/nhess-15-2209-2015

Wang, P.; Kirby, J.H.; Haber, J.D.; Horwitz, M.H.; Knorr, P.O., and Krock, J.R., 2006. Morphological and sedimentological impacts of Hurricane Ivan and immediate poststorm beach recovery along the northwestern Florida barrier-island coasts. Journal of Coastal Research, 22(6), 1382-1402. http://dx.doi.org/10.2112/05-0440.1. 